\title{
Dietary cassava peel meal, methionine, and multi-enzyme supplementation in rabbits' nutrition: effect on growth, digestibility, and carcass traits
}

\author{
Olugbenga D. Oloruntola ${ }^{1,2^{*}}$, Simeon O. Ayodele ${ }^{2}$, Olatunji A. Jimoh² and Johnson O. Agbede ${ }^{3}$
}

\begin{abstract}
Background: This study was carried out to assess the performance indices, nutrient digestibility, and carcass trait of weaner rabbits fed diets containing cassava peel meal (CPM) supplemented with methionine (MET) and multi-enzyme (ENZ). Two hundred and forty 5-week-old growing rabbits were randomly allotted to 8 dietary treatments (10 replicates/treatment) in a factorial arrangement $(2 \times 2 \times 2)$ of 2 CPM inclusion levels $(0$ and 35\%), 2 MET levels (0.56 and 0.83\%), and 2 ENZ levels (0 and 0.05\%).

Results: The final weight gain $(1563.16 \mathrm{~g})$, daily weight gain $(17.67 \mathrm{~g})$, and feed conversion ratio of rabbits fed diet 5 (35\% CPM; 0.56\% MET) were significantly $(P<0.05)$ lower than those fed the rest of the diets. While the 35\% CPM dietary inclusion significantly led to the performance and dry matter digestibility reduction, the high methionine $(0.83 \%)$ and multi-enzyme $(0.05 \%)$ significantly $(P<0.05)$ improved the final weight gain (FWG) and feed and conversion ratio in the rabbits. The interactive effect of methionine and multi-enzyme supplementation on FWG of the rabbits was significant $(P<0.05)$. Dry matter $(D M)$ digestibility decreased $(P<0.05)$ with $C P M$ inclusion, while the DM, organic matter $(\mathrm{OM})$, crude protein (CP), acid detergent fiber, and gross energy (GE) digestibility improved $(P<0.05)$ with high methionine (0.83\%) and enzyme supplementation. The slaughter weight (SLW), carcass weight, and carcass weight percentage of rabbits on diet containing 35\% CPM and 0.56\% methionine but without enzyme supplementation (diet 5) was significantly $(P<0.05)$ lower than the rest of the diets. There were significant $(P<0.05)$ increases in liver and kidney weights of rabbits fed diet 5.
\end{abstract}

Conclusion: The growing rabbit's diet with 35\% CPM inclusion will require the supplementation of methionine at a high level in addition to multi-enzyme supplementation to achieve a desired performance by the farmer.

Keywords: Cassava, Performance, Slaughter traits, Cassava, Methionine, Enzyme, Rabbits

\section{Background}

The supply of balance feeds to monogastric animals in developing countries is a great challenge because of the high cost of protein and energy feed ingredients. This had led to a hike in the prices of finished feeds and the eventual high cost of animal production and products. This situation has

\footnotetext{
* Correspondence: oloruntoladavid@gmail.com;

olugbenga.oloruntola@aaua.edu.ng

${ }^{1}$ Animal Science Department, Adekunle Ajasin University, Akungba Akoko, Nigeria

${ }^{2}$ Agricultural Technology Department, The Federal Polytechnic, Ado Ekiti, Nigeria

Full list of author information is available at the end of the article
}

necessitated the search for alternative feed ingredients to reduce these costs, and the use of agro-industrial byproducts has been identified as a reliable and stable option (Oladunjoye, Ojebiyi, \& Rafiu, 2014).

Cassava (Manihot esculenta) is an important human food resource and animal feed ingredient (Lukuyu, Okike, Duncan, Beveridge, \& Blümmel, 2014). In fact, it is referred to as the African food reserve. Utilization of its peels (5-15\% of tuber weight) in monogastric feeding has been advocated as it has the direct benefit in reducing feeding cost and solving the problem of cassava peel disposal (Oloruntola, Agbede, Onibi, \& Igbasan, 2016). It was 
reported that dried cassava peels can be introduced at $30 \%$ in balanced rations of growing rabbits as the energy source to replace the corresponding amount of maize grain (Agunbiade et al., 1999; Oloruntanyan, Ayoola, Fayeye, Olagunju, \& Olorunsanya, 2007; Omole, 1990). However, the progressive increase in cassava peel inclusion level may pose a threat to the performance and health status of the rabbits. As reported by Aro, Aletor, Tewe, and Agbede (2010) and Kataria (2014), cassava peels, when compared to maize, contain relatively lower crude protein ( 4.20 vs. $8.9 \%)$ and ether extract (3.26 vs. $4.47 \%)$ but higher crude fiber (29.6 vs. $1.38 \%$ ) and ash (7.49 vs. $1.49 \%$ ). Also, the presence of cyanogenic compounds and the high fiber content of cassava peel have been identified as major limitations to its widespread use as the primary feed ingredient in livestock feeding (Aro, 2008). These limitations precipitate negative impacts varying from growth retardation and impaired reproductive capability to death (Lukuyu et al., 2014).

Several processing methods, such as fermentation (Oloruntola, Agbede, Onibi, \& Igbasan, 2015), soaking (Oluremi \& Nwosu, 2002), sun-drying, and cooking (Aro, 2008) and the addition of palm oil, lysine and/or methionine supplementation (Oladunjoye et al., 2014; Ty, Preston, \& Ly, 2003), and enzyme supplementation (Bimrew, 2014; Ogunsipe, Adejumo, Agbede, \& Asaniyan, 2015; Oloruntola, 2018) had been adopted to enhance the utilization of cassava peels in animal feeds.

In the process of detoxifying cyanide to thiocyanate, the enzyme rhodanese makes use of methionine as a sulfur donor; thereby making this amino acid a limiting factor in cassava-based feeds Adegbola, (1977). This forms the basis for suggesting the use of methionine in cassava peel detoxification (Aniebo, 2012; Omole \& Sonaiya, 1981; Oke, 1978). This hypothesis is supported by enhanced overall performance recorded by Oladunjoye et al. (2014) in broiler chicken following $0.4 \%$ methionine supplementation. It is envisaged that the enhanced performance can be further improved with exo-enzyme supplementation as the exo-enzyme has the ability to remove the negative effect of anti-nutritional factors and improves nutrient availability (Kiarie, Romero, \& Nyachoti, 2013). This was supported by the reduction of anti-nutritional effects of hydrogen cyanide and subsequent enhancement of weight gain, feed intake, feed utilization, nutrient digestibility, and nutrient absorption as reported by Midau et al. (2011) due to enzyme supplementation in broiler chickens. Improved food conversation ratio and digestibility in rabbits due to enzyme supplementation were recorded by Ayodele, Oloruntola, and Agbede (2016) and García-Ruiz et al. (2006), respectively. The inclusion of methionine at a level higher than the requirement in combination with a fiberdegrading enzyme in diets of monogastric livestock animals may improve nutrient digestibility and absorption with the resultant enhanced performance of growing rabbits. Majority of the previous studies consider the use of a single approach or method in ameliorating or removing the negative impact of cassava wastes in rabbits' production. Recently, the adoption of multiple methods in ameliorating the negative effects of using agro wastes livestock production was advocated (Adeyeye, Agbede, Aletor, \& Oloruntola, 2018). The use of multiple approaches (methionine and enzyme supplementation) in this study will give room for assessing the efficiency of the individual methods and their interactive effects on the performance of the rabbits being fed a cassava peel-based diet at higher inclusion level. Therefore, the current study was undertaken to assess the effect of two levels of methionine supplementation, two levels of enzyme supplementation, and two levels of cassava peel meal inclusion on performance indices of growing rabbits.

\section{Materials and methods}

Following the approval of the protocol for this experiment by the Centre for Research, Innovation and Development, The Federal Polytechnic, Ado Ekiti, Nigeria, the feeding trial was conducted at the Teaching and Research Farm of Agricultural Technology Department, The Federal Polytechnic, Ado Ekiti, Nigeria. The rabbits were kept in a well-ventilated room. The recommendations and guidelines for applied nutrition experiments in the rabbits were used for the management of the rabbits (Fernández-Carmona et al., 2003).

\section{Experimental diets}

Cassava peels collected fresh from cassava processing factories in Ado Ekiti, Ekiti State, Nigeria, were washed with clean water, drained, spread on a tarpaulin for sun-drying for 12 days, milled with 3-mm screen hammer mill to obtain cassava peel meal (CPM). The chemical composition of CPM is shown in Table 1. The multi-enzyme (Biozyme $\mathrm{PH}$ ) and methionine used for this study were obtained from a commercial feed mill in Akure, Nigeria. The multienzyme (Biozyme $\mathrm{PH}$ ) according to the manufacturer (Biomix S.A, Carrera 47C, Sabaneta-Colombia) has a minimum $/ \mathrm{kg}$ of cellulase (700,000 U.A), $\alpha$-amylase $(800,0$ 00 U.A), $\beta$-glucanase (300,000 U.BG), phytase (1200FTU), protease $(8,000,000$ U.P), lipase (20,000 U.I), and xylanase (500,000 U.X). Eight dietary treatments were formulated in a factorial arrangement $(2 \times 2 \times 2)$ including $2 \mathrm{CPM}$ inclusion ( 0 and 35\%), 2 methionine (MET) levels (0.56 and $0.83 \%$ ) and 2 multi-enzyme (ENZ) levels (0 and $0.05 \%$ ). The eight diets formulated for the rabbits were pelletized (4-mm diameter and 8-mm long) and designated as diets $1,2,3,4,5,6,7$, and 8. Diets 1 and 2 had normal methionine level $(0.56 \%)$ but only diet 2 was supplemented with exo-enzyme; diets 3 and 4 had higher methionine level $(0.83 \%)$, but diet 4 was supplemented with exo-enzyme. In diets 5 and 6, dried cassava peel meal was included at 35\% 
Table 1 Chemical composition ( $\mathrm{g} / \mathrm{kg}$ ) of cassava peels meal

\begin{tabular}{lll}
\hline Parameters & Current experiment & Literature \\
\hline Dry matter & 921.69 & - \\
Crude protein & 54.79 & $48.00^{\mathrm{a}}$ \\
Crude fiber & 105.00 & $210.00^{\mathrm{a}}$ \\
Ether extract & 4.35 & $130.00^{\mathrm{a}}$ \\
Ash & 52.74 & $570.00^{\mathrm{a}}$ \\
Nitrogen-free extract & 704.81 & - \\
Neutral detergent fiber & 219.43 & $196.00^{\mathrm{a}}$ \\
Acid detergent fiber & 136.44 & $171.00^{\mathrm{a}}$ \\
Acid detergent lignin & 22.16 & $72.00^{\mathrm{a}}$ \\
Hydrocyanic acid & 0.02 & $33-1081 \mathrm{mg} / \mathrm{kg}$ \\
Methionine & 0.36 & $0.30^{\mathrm{c}}$ \\
Lysine & 1.14 & $1.11^{\mathrm{c}}$ \\
\hline
\end{tabular}

aINRA., CIRAD., AFZ., FAO (2012), 'bukuyu et al. (2014), 'Oladunjoye et al. (2014) to replace the corresponding amount of maize grain and had normal methionine level (0.56\%), but diet 6 was supplemented with multi-enzyme. Diets 7 and 8 had their maize grain being replaced by $35 \%$ of dried cassava peel meal and had higher methionine level $(0.83 \%)$ but diet 8 was multi-enzyme supplemented (Table 2).

\section{Animal management}

The rabbits were managed in line with the recommendations and guidelines for applied nutrition experiments in rabbits (Fernández-Carmona et al., 2003). A total of 240, cross breeds (Chinchilla and New Zealand white) of equal sex, at 35 days of age with the average size of $572.99 \pm 9.33$ were randomly allotted to 8 dietary treatments $(30$ rabbits/diet, 10 replicates/diet, 3 rabbits/replicate). The rabbits were housed in galvanized wire mesh cages $(60 \times$ $49 \times 30 \mathrm{~cm}) \mathrm{kept}$ in a well-ventilated pen. The respective

Table 2 Composition of experimental diets

\begin{tabular}{|c|c|c|c|c|c|c|c|c|}
\hline Ingredients (\%) & Diet 1 & Diet 2 & Diet 3 & Diet 4 & Diet 5 & Diet 6 & Diet 7 & Diet 8 \\
\hline Multi-enzyme (0.05\%) & - & + & - & + & - & + & - & + \\
\hline DL-Methionine (99\%) & 0.18 & 0.18 & 0.48 & 0.48 & 0.26 & 0.26 & 0.55 & 0.55 \\
\hline Cassava peel meal & 0.00 & 0.00 & 0.00 & 0.00 & 35.00 & 35.00 & 35.00 & 35.00 \\
\hline Maize & 37.00 & 37.00 & 37.00 & 37.00 & 1.93 & 1.93 & 1.93 & 1.93 \\
\hline BDG & 36.80 & 36.80 & 36.80 & 36.80 & 36.80 & 36.80 & 36.80 & 36.80 \\
\hline Soybean meal & 8.00 & 8.00 & 8.00 & 8.00 & 8.00 & 8.00 & 8.00 & 8.00 \\
\hline Maize husk & 8.00 & 8.00 & 8.00 & 8.00 & 8.00 & 8.00 & 8.00 & 8.00 \\
\hline Wheat offal & 7.37 & 7.37 & 7.07 & 7.07 & 7.36 & 7.36 & 7.07 & 7.07 \\
\hline Bone & 1.00 & 1.00 & 1.00 & 1.00 & 1.00 & 1.00 & 1.00 & 1.00 \\
\hline Vegetable oil & 1.00 & 1.00 & 1.00 & 1.00 & 1.00 & 1.00 & 1.00 & 1.00 \\
\hline Premix & 0.25 & 0.25 & 0.25 & 0.25 & 0.25 & 0.25 & 0.25 & 0.25 \\
\hline Salt & 0.20 & 0.20 & 0.20 & 0.20 & 0.20 & 0.20 & 0.20 & 0.20 \\
\hline L-Lysine $\mathrm{HCl}(78 \%)$ & 0.20 & 0.20 & 0.20 & 0.20 & 0.20 & 0.20 & 0.20 & 0.20 \\
\hline \multicolumn{9}{|l|}{ Calculated analysis } \\
\hline Lysine & 0.88 & 0.88 & 0.88 & 0.88 & 0.87 & 0.87 & 0.87 & 0.87 \\
\hline Methionine & 0.56 & 0.56 & 0.83 & 0.83 & 0.56 & 0.56 & 0.83 & 0.83 \\
\hline Calcium & 0.49 & 0.49 & 0.49 & 0.49 & 0.57 & 0.57 & 0.57 & 0.57 \\
\hline Available P & 0.35 & 0.35 & 0.36 & 0.36 & 0.39 & 0.39 & 0.39 & 0.39 \\
\hline D. energy (kcal/kg) & 2581.5 & 2581.5 & 2577.6 & 2577.6 & 2624.5 & 2624.5 & 2620.7 & 2620.7 \\
\hline \multicolumn{9}{|l|}{ Determined analysis } \\
\hline Crude protein & 17.51 & 17.53 & 17.46 & 17.47 & 16.55 & 16.53 & 16.49 & 16.47 \\
\hline Crude fiber & 12.09 & 12.06 & 12.07 & 12.03 & 16.25 & 16.23 & 16.21 & 16.23 \\
\hline Lysine & 0.90 & 0.92 & 0.92 & 0.91 & 0.89 & 0.90 & 0.89 & 0.91 \\
\hline Methionine & 0.58 & 0.59 & 0.86 & 0.85 & 0.59 & 0.57 & 0.85 & 0.84 \\
\hline NDF & 39.96 & 39.94 & 39.95 & 39.94 & 40.12 & 40.15 & 40.13 & 40.14 \\
\hline ADF & 17.52 & 17.54 & 17.36 & 17.34 & 17.98 & 17.92 & 17.95 & 19.99 \\
\hline $\mathrm{ADL}$ & 3.61 & 3.64 & 3.63 & 3.62 & 3.97 & 3.94 & 3.96 & 3.98 \\
\hline
\end{tabular}


experimental diets and fresh water were provided ad libitum for the animals for a period of eight weeks.

\section{Response criteria}

During the 8 weeks of the experiment, the body weight and feed consumption of the rabbits were measured and recorded weekly. Daily weight gain and feed conversion were thereafter calculated. The mortality was also recorded. The digestibility trial was carried out in accordance with the recommendation and guidelines for applied nutrition experiments in rabbits (Fernández-Carmona et al., 2003). Eight 45-day-old rabbits were selected from each diet and caged individually in metabolism cages $(55 \times 35 \times 26 \mathrm{~cm})$. After the adaptation period of seven days, the hard feces were collected daily for 4 days at approximately 08:00 GMT each morning before serving the ration for the day, bulked in polythene bags and thereafter stored in a freezer $\left(-18^{\circ} \mathrm{C}\right)$ until chemical analysis. On day 56 of the experiment, one rabbit/cage (10 rabbits/diet) was selected, weighed, tagged, starved overnight and slaughtered (at 8:00 GMT) in accordance with the guidelines of World Rabbit Science Association (Oloruntola et al., 2016). The removal of skin, head, limb, and evisceration of the carcass was done. Thereafter, dressing out percentage was calculated while weights of the various internal organs (liver, lungs, kidneys, gall-bladder, heart, and spleen) were determined separately and their relative weight calculated as the percentage of slaughter weight.

\section{Chemical analysis}

The cassava peel meal and other feed resources used (maize, brewers' dried grain (BDG), wheat offal, soybean meal, maize husk) were analyzed for, while the experimental diets and feces were analyzed in duplicate by AOAC (2000) methods to determine the concentration of moisture (method no. 934.01), protein (method no. 2001.11), fat (method no. 988.05), ash (method no. 996.11), and crude fiber (method no. 978.10). Organic matter and gross energy were also determined (EGRAN, 2001). Neutral detergent fiber and acid detergent fiber were determined using Van Soest method (Goering \& VanSoest, 1970). The cyanide was determined using the silver nitrate method (Oboh, Akindahunsi, \& Oshodi, 2002). Lysine and methionine contents of the feed and cassava peel meal were determined with Applied Biosystems PTH Amino Acid Analyser (Applied Biosystems Inc. Foster City, CA, 94404, USA, Model 120A) using methods described by Benitez (1989).

\section{Statistical analysis}

Statistical analysis was carried out with SPSS version 20 . Data generated were analyzed as the $2 \times 2 \times 2$ factorial arrangement with 2 levels of cassava peels, 2 levels of methionine, and 2 levels of multi-enzyme and test for significance between the dietary treatment means by Duncan's Multiple Range Test at $P \leq 0.05$.

\section{Results}

The results of the chemical analysis of the cassava peel meal used in this study showed variations from the reference (Table 1). Table 3 showed the growth performance of rabbits fed the experimental diets. The final weight gain (1563.16 g/rabbit), daily weight gain (17.67 g/rabbit), and feed conversion ratio (FCR) of rabbits fed on CPM $(35 \%$ $\mathrm{CPM})$ inclusion with normal methionine (0.56\% MET) inclusion diet (Diet 5$)$ were significantly $(P<0.01)$ lower than those fed the rest of the diets (except for the control diet for FCR). In addition, cassava peel meal (CPM) inclusion at $35 \%$ in the diet significantly $(P<0.05)$ reduced the final weight gain (FWG) and daily weight gain (DWG) of the rabbits from 1715.95 to $1673.64 \mathrm{~g}$ and 20.40 to 19.65 $\mathrm{g} /$ rabbit, respectively. The high methionine $(0.83 \% \mathrm{MET})$ addition to the diets significantly $(P<0.01 ; 0.05)$ improved the DWG and FCR of rabbits by $4.75 \%$ and $6.37 \%$, respectively. Also, the multi-enzyme supplementation had a positive significant $(P<0.01 ; 0.05)$ influence on the weight changes of the growing rabbits. The interactive effect of methionine and multi-enzyme supplementation on FWG and DWG of the rabbits was significant $(P<0.05)$. Data on nutrient utilization are shown in Table 4. The digestibility of dry matter (DM), organic matter (OM), crude protein $(\mathrm{CP})$, neutral detergent fiber (NDF), acid detergent fiber (ADF), and gross energy (GE) by the rabbits was lower significantly $(P<0.01 ; 0.05)$ in those fed diet $5(35 \%$ CPM; $0.56 \%$ MET) than those fed other diets. There was significant $(P<0.05)$ improvement in DM, OM, CP, ADF, and GE digestibility recorded due to relatively high $(0.83 \%$ MET) methionine supplementation especially in diets containing CPM at 35\%. The interactive effects of methionine and enzyme supplementation on CP and GE digestibility were also significant $(P<0.01)$ (Table 5$)$. The slaughter weight (SLW), carcass weight (CWT), and carcass weight percentage (CWP) of rabbits on diet 5 (35\% CPM; $0.56 \% \mathrm{MET})$ were significantly $(P<0.01)$ lower than those fed the rest of the test diets. The relative weights of the lung, gallbladder, heart, and spleen were stable $(P>0.05)$ across the diets (Table 6). However, there were significant $(P<0.01)$ increase in the liver and kidney weights of rabbits fed diet 5 .

\section{Discussion}

The observed variation in the chemical composition of cassava peel meal used in this study and those reported by INRA., CIRAD., AFZ., FAO (2012), Lukuyu et al. (2014), and Oladunjoye et al. (2014) may be due to environmental and genotypic variation (Burns et al., 2012). The observed lower final weight gain (FWG), daily weight gain (DWG), and FCR of rabbits fed on CPM (35\% CPM) inclusion with 
Table 3 Effect of cassava peel meal inclusion (\%), methionine (\%), and multi-enzyme (\%) supplementation on growth performance in rabbits

\begin{tabular}{|c|c|c|c|c|c|c|c|c|c|c|}
\hline Diets & CPM & MET & ENZ & IW & FWG & DWG & TFI & DFI & FCR & MOR \\
\hline 1 & 0 & 0.56 & 0.00 & 571.88 & $1681.16^{\mathrm{a}}$ & $19.80^{a}$ & 2957.54 & 52.81 & $2.66^{\mathrm{ab}}$ & 1.00 \\
\hline 2 & 0 & 0.56 & 0.05 & 572.70 & $1728.13^{\mathrm{a}}$ & $20.63^{a}$ & 2935.84 & 52.42 & $2.54^{b}$ & 0.66 \\
\hline 3 & 0 & 0.83 & 0.00 & 575.03 & $1724.10^{\mathrm{a}}$ & $20.51^{a}$ & 2828.37 & 50.50 & $2.46^{\mathrm{b}}$ & 0.66 \\
\hline 4 & 0 & 0.83 & 0.05 & 572.80 & $1730.40^{\mathrm{a}}$ & $20.67^{a}$ & 2916.82 & 50.08 & $2.52^{b}$ & 0.66 \\
\hline 5 & 35 & 0.56 & 0.00 & 573.10 & $1563.16^{b}$ & $17.67^{b}$ & 2865.68 & 51.17 & $2.89^{a}$ & 1.33 \\
\hline 6 & 35 & 0.56 & 0.05 & 574.73 & $1697.50^{\mathrm{a}}$ & $20.04^{\mathrm{a}}$ & 2896.66 & 51.72 & $2.58^{\mathrm{b}}$ & 1.00 \\
\hline 7 & 35 & 0.83 & 0.00 & 570.88 & $1715.12^{\mathrm{a}}$ & $20.43^{\mathrm{a}}$ & 2878.00 & 51.39 & $2.52^{b}$ & 1.00 \\
\hline 8 & 35 & 0.83 & 0.05 & 572.76 & $1718.80^{\mathrm{a}}$ & $20.46^{a}$ & 2871.65 & 51.27 & $2.51^{b}$ & 0.66 \\
\hline SEM & & & & 1.90 & 13.07 & 0.23 & 0.23 & 0.42 & 0.04 & 0.12 \\
\hline$P$ value & & & & 1.000 & 0.01 & 0.01 & 0.94 & 0.94 & 0.05 & 0.88 \\
\hline \multicolumn{11}{|l|}{ Main effects } \\
\hline \multirow[t]{2}{*}{ CPM } & 0 & & & 573.10 & $1715.95^{\mathrm{a}}$ & $20.40^{a}$ & 2909.64 & 51.95 & 2.54 & 0.75 \\
\hline & 35 & & & 572.87 & $1673.64^{b}$ & $19.65^{b}$ & 2878.00 & 51.39 & 2.68 & 1.00 \\
\hline SEM & & & & 3.19 & 12.30 & 0.22 & 38.07 & 0.68 & 0.05 & 0.19 \\
\hline$P$ value & & & & 0.96 & 0.03 & 0.03 & 0.57 & 0.57 & 0.25 & 0.38 \\
\hline \multirow[t]{2}{*}{ MET } & & 0.56 & & 573.11 & $1667.49^{b}$ & $19.54^{b}$ & 2913.93 & 52.03 & $2.67^{a}$ & 1.00 \\
\hline & & 0.83 & & 572.86 & $1722.10^{\mathrm{a}}$ & $20.52^{a}$ & 2873.71 & 51.31 & $2.50^{b}$ & 0.75 \\
\hline SEM & & & & 3.19 & 12.30 & 0.22 & 38.07 & 0.68 & 0.05 & 0.19 \\
\hline$P$ value & & & & 0.95 & 0.01 & 0.01 & 0.46 & 0.46 & 0.02 & 0.37 \\
\hline \multirow[t]{2}{*}{ ENZ } & & & 0.0 .00 & 572.72 & $1670.88^{b}$ & $19.61^{b}$ & 2882.40 & 51.47 & 2.63 & 1.00 \\
\hline & & & 0.05 & 573.26 & $1718.70^{a}$ & $20.45^{a}$ & 2905.24 & 51.87 & 2.54 & 0.75 \\
\hline SEM & & & & 3.19 & 12.30 & 0.22 & 38.07 & 0.68 & 0.05 & 0.19 \\
\hline$P$ value & & & & 0.91 & 0.01 & 0.02 & 0.68 & 0.68 & 0.16 & 0.38 \\
\hline \multicolumn{11}{|l|}{ Interactions } \\
\hline \multicolumn{11}{|l|}{ CPM*MET } \\
\hline SEM & & & & 4.51 & 17.40 & 0.31 & 53.84 & 0.96 & 0.66 & 0.27 \\
\hline$P$ value & & & & 0.68 & 0.08 & 0.07 & 0.53 & 0.53 & 0.40 & 0.76 \\
\hline \multicolumn{11}{|l|}{$C P M *{ }^{*}$ NZZ } \\
\hline SEM & & & & 4.51 & 17.40 & 0.31 & 53.84 & 0.96 & 0.66 & 0.27 \\
\hline$P$ value & & & & 0.78 & 0.24 & 0.27 & 0.84 & 0.84 & 0.36 & 0.76 \\
\hline \multicolumn{11}{|l|}{ MET*ENZ } \\
\hline SEM & & & & 4.51 & 17.40 & 0.31 & 53.84 & 0.96 & 0.66 & 0.27 \\
\hline$P$ value & & & & 0.87 & 0.03 & 0.03 & 0.74 & 0.74 & 0.08 & 0.76 \\
\hline \multicolumn{11}{|c|}{$\mathrm{CPM}^{*} \mathrm{MET}^{*} \mathrm{ENZ}$} \\
\hline SEM & & & & 6.39 & 24.61 & 0.44 & 76.14 & 1.36 & 0.09 & 0.39 \\
\hline$P$ value & & & & 0.85 & 0.21 & 0.20 & 0.50 & 0.50 & 0.66 & 0.76 \\
\hline
\end{tabular}

CPM Cassava peel meal, MET Methionine, ENZ Enzyme, IW Initial weight (g/bird), FWG Final weight gain (g/bird), DWG Daily weight gain (g/bird), TFI Total feed intake (g/bird), DFI Daily feed intake (g/bird), FCR Feed conversion rate, MOR mortality (\%)

normal methionine $(0.56 \%$ MET) inclusion diet (Diet 5$)$ when compared to other rabbits fed the rest of the diets, and the negative effects of 35\% CPM cassava peels inclusion level on FWG and DWG of the rabbits in this study is similar to growth depression was recorded by Agunbiade, Adeyemi, Fasina, Ashorobi, Adebanjo, \& Waide
(1999) and Iyayi and Odueso (2003) in rabbits due to the dietary inclusion of cassava peel and cyanide, respectively. This finding indicates that rabbits may not be able to tolerate the inclusion of CPM at 35\% without experiencing growth depression. This may be attributed to the cumulative effect of the anti-nutritive effect of $\mathrm{HCN}$ present in 
Table 4 Effect of cassava peel meal inclusion (\%), methionine (\%) and multi-enzyme (\%) supplementation on nutrient utilization (\%) in rabbits

\begin{tabular}{|c|c|c|c|c|c|c|c|c|c|c|c|}
\hline Diets & CPM & MET & ENZ & $\mathrm{FI}$ & $\mathrm{DM}$ & $\mathrm{OM}$ & $\mathrm{CP}$ & CF & NDF & ADF & GE \\
\hline 1 & 0 & 0.56 & 0.00 & 44.39 & $63.12^{\mathrm{bc}}$ & $64.75^{\mathrm{ab}}$ & $68.80^{\mathrm{a}}$ & 49.93 & $52.37^{\mathrm{bc}}$ & $36.74^{\mathrm{ab}}$ & $64.71^{b}$ \\
\hline 2 & 0 & 0.56 & 0.05 & 43.72 & $68.47^{\mathrm{ab}}$ & $68.53^{\mathrm{a}}$ & $74.06^{\mathrm{a}}$ & 55.20 & $57.87^{\mathrm{ab}}$ & $45.08^{\mathrm{ab}}$ & $74.13^{\mathrm{a}}$ \\
\hline 3 & 0 & 0.83 & 0.00 & 42.19 & $68.79^{a}$ & $68.52^{\mathrm{a}}$ & $74.40^{\mathrm{a}}$ & 53.38 & $55.32^{\mathrm{abc}}$ & $45.86^{\mathrm{ab}}$ & $73.42^{\mathrm{a}}$ \\
\hline 4 & 0 & 0.83 & 0.05 & 43.67 & $70.91^{a}$ & $70.16^{\mathrm{a}}$ & $73.73^{\mathrm{a}}$ & 55.45 & $59.71^{\mathrm{a}}$ & $46.14^{a}$ & $74.57^{\mathrm{a}}$ \\
\hline 5 & 35 & 0.56 & 0.00 & 43.06 & $61.28^{c}$ & $61.47^{b}$ & $61.86^{\mathrm{b}}$ & 48.33 & $50.31^{c}$ & $33.87^{b}$ & $62.68^{\mathrm{b}}$ \\
\hline 6 & 35 & 0.56 & 0.05 & 43.36 & $65.51^{\mathrm{abc}}$ & $66.69^{\mathrm{ab}}$ & $73.94^{\mathrm{a}}$ & 54.99 & $57.98^{\mathrm{ab}}$ & $45.09^{\mathrm{ab}}$ & $74.48^{\mathrm{a}}$ \\
\hline 7 & 35 & 0.83 & 0.00 & 42.97 & $65.39^{\mathrm{abc}}$ & $67.28^{\mathrm{ab}}$ & $74.16^{\mathrm{a}}$ & 53.64 & $53.47^{\mathrm{abc}}$ & $45.01^{\mathrm{ab}}$ & $74.01^{\mathrm{a}}$ \\
\hline 8 & 35 & 0.83 & 0.05 & 43.85 & $69.30^{a}$ & $70.11^{\mathrm{a}}$ & $74.70^{\mathrm{a}}$ & 55.79 & $59.73^{\mathrm{a}}$ & $45.50^{\mathrm{ab}}$ & $74.41^{\mathrm{a}}$ \\
\hline SEM & & & & 0.41 & 0.82 & 0.81 & 1.04 & 0.94 & 0.88 & 1.40 & 1.22 \\
\hline$P$ value & & & & 0.96 & 0.01 & 0.05 & 0.01 & 0.40 & 0.02 & 0.16 & 0.02 \\
\hline \multicolumn{12}{|l|}{ Main effect } \\
\hline \multirow[t]{2}{*}{ CPM } & 0 & & & 43.50 & $67.82^{a}$ & 67.99 & 72.75 & 53.49 & 56.32 & 43.46 & 71.71 \\
\hline & 35 & & & 43.06 & $65.37^{b}$ & 66.39 & 71.16 & 53.19 & 55.37 & 42.37 & 71.39 \\
\hline SEM & & & & 0.66 & 0.85 & 0.99 & 0.95 & 1.31 & 0.94 & 1.78 & 1.29 \\
\hline$P$ value & & & & 0.65 & 0.05 & 0.26 & 0.25 & 0.87 & 0.49 & 0.67 & 0.86 \\
\hline \multirow[t]{2}{*}{ MET } & & 0.56 & & 43.63 & $64.59^{b}$ & $65.36^{b}$ & $69.66^{b}$ & 52.11 & 54.63 & $40.19^{b}$ & $69.01^{b}$ \\
\hline & & 0.83 & & 42.92 & $68.60^{\mathrm{a}}$ & $69.02^{\mathrm{a}}$ & $74.24^{\mathrm{a}}$ & 54.56 & 57.06 & $46.63^{a}$ & $74.10^{\mathrm{a}}$ \\
\hline SEM & & & & 0.66 & 0.85 & 0.99 & 0.95 & 1.31 & 0.94 & 1.78 & 1.29 \\
\hline$P$ value & & & & 0.46 & 0.00 & 0.02 & 0.00 & 0.20 & 0.08 & 0.04 & 0.01 \\
\hline \multirow[t]{2}{*}{ ENZ } & & & 0.00 & 43.15 & $64.64^{b}$ & $65.50^{\mathrm{b}}$ & $69.80^{b}$ & $51.32^{b}$ & $52.87^{b}$ & 40.37 & $68.70^{b}$ \\
\hline & & & 0.05 & 43.40 & $68.54^{\mathrm{a}}$ & $68.87^{\mathrm{a}}$ & $74.11^{\mathrm{a}}$ & $55.36^{\mathrm{a}}$ & $58.82^{\mathrm{a}}$ & 45.45 & $74.40^{\mathrm{a}}$ \\
\hline SEM & & & & 0.66 & 0.85 & 0.99 & 0.95 & 1.31 & 0.94 & 1.78 & 1.29 \\
\hline$P$ value & & & & 0.79 & 0.01 & 0.02 & 0.01 & 0.04 & 0.00 & 0.06 & 0.01 \\
\hline \multicolumn{12}{|l|}{ Interactions } \\
\hline \multicolumn{12}{|l|}{ CPM*MET } \\
\hline SEM & & & & 0.94 & 1.21 & 1.40 & 1.35 & 1.85 & 1.33 & 2.52 & 1.82 \\
\hline$P$ value & & & & 0.66 & 0.96 & 0.50 & 0.16 & 0.74 & 0.98 & 0.89 & 0.77 \\
\hline \multicolumn{12}{|l|}{ CPM ${ }^{*}$ ENZ } \\
\hline SEM & & & & 0.94 & 1.21 & 1.40 & 1.35 & 1.85 & 1.33 & 2.52 & 1.82 \\
\hline$P$ value & & & & 0.87 & 0.89 & 0.64 & 0.15 & 0.84 & 0.46 & 0.76 & 0.82 \\
\hline \multicolumn{12}{|l|}{ MET*ENZ } \\
\hline SEM & & & & 0.94 & 1.21 & 1.40 & 1.35 & 1.85 & 1.33 & 2.52 & 1.82 \\
\hline$P$ value & & & & 0.65 & 0.47 & 0.42 & 0.01 & 0.31 & 0.64 & 0.08 & 0.01 \\
\hline \multicolumn{12}{|c|}{$\mathrm{CPM}^{*} \mathrm{MET}^{*}$ ENZ } \\
\hline SEM & & & & 1.33 & 1.71 & 1.98 & 1.91 & 2.61 & 1.88 & 3.57 & 2.58 \\
\hline$P$ value & & & & 0.51 & 0.55 & 0.96 & 0.31 & 0.86 & 0.95 & 0.79 & 0.67 \\
\hline
\end{tabular}

CPM Cassava peel meal, MET Methionine, ENZ Enzyme, FI Feed intake, DM Dry matter, OM Organic matter, CP Crude protein, CF Crude fiber, NDF Neutral detergent fiber, ADF Acid detergent fiber, GE Gross energy

CPM, which has the ability to inhibit several enzyme systems (Enneking \& Wink, 2000; Francis, Makkar \& Becker, 2001) with a concomitant growth depression as a result of interference with certain essential amino acids which could lead to decline in the utilization of associated nutrients (Olowoyeye, 2016). The improved the DWG and
FCR of rabbits due to the high methionine $(0.83 \%$ MET) addition to the diets is consistent with the findings of Oladunjoye et al. (2014) who reported improvement in the performance of broilers fed cassava peel meal-based diet supplemented with a higher level of methionine. The improved weight changes and FCR of rabbits on diets 
Table 5 Effect of cassava peel meal inclusion (\%), methionine (\%) and multi-enzyme (\%) supplementation on the carcass of rabbits

\begin{tabular}{|c|c|c|c|c|c|c|}
\hline Diets & CPM & MET & ENZ & SLW (g) & CWT (g) & CWP (\%) \\
\hline 1 & 0 & 0.56 & 0.00 & $1659.62^{\mathrm{a}}$ & $926.41^{a}$ & $55.78^{a}$ \\
\hline 2 & 0 & 0.56 & 0.05 & $1706.59^{\mathrm{a}}$ & $973.38^{\mathrm{a}}$ & $57.03^{a}$ \\
\hline 3 & 0 & 0.83 & 0.00 & $1702.56^{\mathrm{a}}$ & $969.35^{\mathrm{a}}$ & $56.92^{\mathrm{a}}$ \\
\hline 4 & 0 & 0.83 & 0.05 & $1708.90^{\mathrm{a}}$ & $975.64^{\mathrm{a}}$ & $57.07^{\mathrm{a}}$ \\
\hline 5 & 35 & 0.56 & 0.00 & $1541.76^{\mathrm{b}}$ & $808.41^{b}$ & $52.41^{b}$ \\
\hline 6 & 35 & 0.56 & 0.05 & $1676.01^{a}$ & $942.74^{a}$ & $56.21^{\mathrm{a}}$ \\
\hline 7 & 35 & 0.83 & 0.00 & $1693.58^{\mathrm{a}}$ & $960.36^{a}$ & $56.69^{a}$ \\
\hline 8 & 35 & 0.83 & 0.05 & $1697.26^{\mathrm{a}}$ & $964.04^{\mathrm{a}}$ & $56.77^{\mathrm{a}}$ \\
\hline \multicolumn{4}{|l|}{ SEM } & 13.06 & 13.07 & 0.35 \\
\hline \multicolumn{4}{|l|}{$P$ value } & 0.01 & 0.01 & 0.01 \\
\hline \multicolumn{7}{|c|}{ Main effect } \\
\hline \multirow[t]{2}{*}{ CPM } & 0 & & & $1694.42^{\mathrm{a}}$ & $961.19^{\mathrm{a}}$ & $56.70^{\mathrm{a}}$ \\
\hline & 35 & & & $1652.15^{b}$ & $918.89^{b}$ & $55.52^{b}$ \\
\hline \multicolumn{2}{|c|}{ SEM } & & & 12.31 & 12.30 & 0.32 \\
\hline \multicolumn{2}{|c|}{$P$ value } & & & 0.02 & 0.02 & 0.02 \\
\hline \multirow[t]{2}{*}{ MET } & & 0.56 & & $1694.42^{\mathrm{a}}$ & $961.19^{\mathrm{a}}$ & $56.70^{\mathrm{a}}$ \\
\hline & & 0.83 & & $1652.15^{\mathrm{b}}$ & $918.89^{b}$ & $55.52^{b}$ \\
\hline \multicolumn{2}{|c|}{ SEM } & & & 12.31 & 12.30 & 0.32 \\
\hline \multicolumn{2}{|c|}{$P$ value } & & & 0.01 & 0.01 & 0.01 \\
\hline \multirow{2}{*}{\multicolumn{2}{|c|}{ ENZ }} & & 0.00 & $1649.38^{b}$ & $916.13^{b}$ & $55.45^{b}$ \\
\hline & & & 0.05 & $1697.19^{a}$ & $963.95^{\mathrm{a}}$ & $56.77^{a}$ \\
\hline \multicolumn{2}{|c|}{ SEM } & & & 12.31 & 12.30 & 0.32 \\
\hline \multicolumn{2}{|c|}{$P$ value } & & & 0.01 & 0.01 & 0.01 \\
\hline \multicolumn{7}{|c|}{ Interactions } \\
\hline \multicolumn{7}{|c|}{ CPM*MET } \\
\hline \multicolumn{2}{|c|}{ SEM } & & & 17.41 & 17.40 & 0.45 \\
\hline \multicolumn{2}{|c|}{$P$ value } & & & 0.08 & 0.08 & 0.06 \\
\hline \multicolumn{7}{|c|}{ CPM*ENZ } \\
\hline \multicolumn{2}{|c|}{ SEM } & & & 17.41 & 17.40 & 0.45 \\
\hline \multicolumn{2}{|c|}{$P$ value } & & & 0.24 & 0.24 & 0.19 \\
\hline \multicolumn{7}{|c|}{ MET*ENZ } \\
\hline \multicolumn{2}{|c|}{ SEM } & & & 17.41 & 17.40 & 0.45 \\
\hline \multicolumn{2}{|c|}{$P$ value } & & & 0.02 & 0.02 & 0.01 \\
\hline \multicolumn{7}{|c|}{$\mathrm{CPM}^{*} \mathrm{MET}^{*} \mathrm{ENZ}$} \\
\hline \multicolumn{2}{|c|}{ SEM } & & & 24.62 & 24.61 & 0.64 \\
\hline \multicolumn{2}{|c|}{$P$ value } & & & 0.21 & 0.21 & 0.16 \\
\hline
\end{tabular}

CPM Cassava peel meal, MET Methionine, ENZ Enzyme, SLW Slaughter weight, CWT Carcass weight, CWP Carcass weight percentage

containing $0.83 \%$ as against $0.56 \%$ methionine level in this study further suggest that the excess addition of methionine might have averted the occurrence of sulfur-containing amino acid imbalance usually experienced in animals due to increase in detoxification of cyanide (Lukuyu et al., 2014)
Table 6 Effect of cassava peel meal inclusion (\%), methionine (\%) and multi-enzyme (\%) supplementation on relative internal organ weight (\%) of rabbits

\begin{tabular}{|c|c|c|c|c|c|c|c|c|c|}
\hline DIETS & CPM & MET & ENZ & LIV & LUN & KID & $\mathrm{GBL}$ & HEA & SPL \\
\hline 1 & 0 & 0.56 & 0.00 & $3.27^{b}$ & 0.68 & $0.56^{b}$ & 0.06 & 0.43 & 0.02 \\
\hline 2 & 0 & 0.56 & 0.05 & $3.22^{\mathrm{b}}$ & 0.66 & $0.55^{\mathrm{b}}$ & 0.05 & 0.41 & 0.02 \\
\hline 3 & 0 & 0.83 & 0.00 & $3.24^{b}$ & 0.65 & $0.54^{\mathrm{b}}$ & 0.06 & 0.39 & 0.02 \\
\hline 4 & 0 & 0.83 & 0.05 & $3.18^{b}$ & 0.67 & $0.50^{\mathrm{b}}$ & 0.05 & 0.40 & 0.02 \\
\hline 5 & 35 & 0.56 & 0.00 & $4.28^{a}$ & 0.86 & $0.82^{\mathrm{a}}$ & 0.06 & 0.48 & 0.02 \\
\hline 6 & 35 & 0.56 & 0.05 & $3.43^{\mathrm{b}}$ & 0.64 & $0.56^{\mathrm{b}}$ & 0.05 & 0.41 & 0.02 \\
\hline 7 & 35 & 0.83 & 0.00 & $3.31^{\mathrm{b}}$ & 0.63 & $0.55^{\mathrm{b}}$ & 0.05 & 0.43 & 0.02 \\
\hline 8 & 35 & 0.83 & 0.05 & $3.32^{\mathrm{b}}$ & 0.68 & $0.56^{\mathrm{b}}$ & 0.05 & 0.42 & 0.03 \\
\hline SEM & & & & 0.88 & 0.04 & 0.02 & 0.00 & 0.01 & 0.00 \\
\hline$P$ value & & & & 0.01 & 0.93 & 0.01 & 0.99 & 0.72 & 0.99 \\
\hline \multicolumn{10}{|c|}{ Main effect } \\
\hline \multirow[t]{2}{*}{ CPM } & 0 & & & $3.23^{b}$ & 0.67 & $0.54^{b}$ & 0.06 & 0.41 & 0.02 \\
\hline & 35 & & & $3.59^{\mathrm{a}}$ & 0.70 & $0.62^{\mathrm{a}}$ & 0.05 & 0.44 & 0.02 \\
\hline \multicolumn{2}{|c|}{ SEM } & & & 0.09 & 0.06 & 0.02 & 0.01 & 0.29 & 0.01 \\
\hline \multicolumn{2}{|c|}{$P$ value } & & & 0.01 & 0.72 & 0.02 & 0.95 & 0.23 & 0.61 \\
\hline \multirow[t]{2}{*}{ MET } & & 0.56 & & $3.56^{\mathrm{a}}$ & 0.67 & $0.54^{b}$ & 0.06 & 0.41 & 0.02 \\
\hline & & 0.83 & & $3.27^{b}$ & 0.70 & $0.62^{\mathrm{a}}$ & 0.05 & 0.44 & 0.02 \\
\hline \multicolumn{2}{|c|}{ SEM } & & & 0.09 & 0.06 & 0.02 & 0.01 & 0.29 & 0.01 \\
\hline \multicolumn{2}{|c|}{$P$ value } & & & 0.04 & 0.58 & 0.02 & 0.85 & 0.36 & 0.75 \\
\hline \multirow{2}{*}{\multicolumn{2}{|c|}{ ENZ }} & & 0.00 & 3.53 & 0.70 & $0.62^{\mathrm{a}}$ & 0.06 & 0.43 & 0.02 \\
\hline & & & 0.05 & 3.29 & 0.66 & $0.54^{b}$ & 0.05 & 0.41 & 0.02 \\
\hline \multicolumn{2}{|c|}{ SEM } & & & 0.09 & 0.06 & 0.02 & 0.01 & 0.29 & 0.01 \\
\hline \multicolumn{2}{|c|}{$P$ value } & & & 0.08 & 0.65 & 0.02 & 0.54 & 0.41 & 0.83 \\
\hline
\end{tabular}

Interactions

CPM*MET

$\begin{array}{lllllll}\text { SEM } & 0.13 & 0.09 & 0.03 & 0.01 & 0.02 & 0.00\end{array}$

CPM*ENZ

\begin{tabular}{|c|c|c|c|c|c|c|}
\hline SEM & 0.13 & 0.09 & 0.03 & 0.01 & 0.02 & 0.00 \\
\hline$P$ value & 0.17 & 0.66 & 0.15 & 0.91 & 0.45 & 0.87 \\
\hline \multicolumn{7}{|l|}{ MET*ENZ } \\
\hline SEM & 0.13 & 0.09 & 0.03 & 0.01 & 0.02 & 0.00 \\
\hline$P$ value & 0.12 & 0.40 & 0.10 & 0.82 & 0.25 & 0.95 \\
\hline \multicolumn{7}{|c|}{$\mathrm{CPM}^{*} \mathrm{MET}^{*} \mathrm{ENZ}$} \\
\hline SEM & 0.18 & 0.13 & 0.04 & 0.01 & 0.03 & p1 \\
\hline$P$ value & 0.11 & 0.53 & 0.03 & 0.94 & 0.83 & \\
\hline
\end{tabular}

CPM Cassava peel meal, MET Methionine, ENZ Enzyme, LIV Liver, LUN Lung, KID Kidney, GBL Gallbladder, HEA Heart, SPL Spleen

. This is because the enzyme rhodanese makes use of methionine as the sulfur donor to detoxify cyanide to thiocyanate and thus makes methionine a limiting amino acid (AA) in animals fed cassava peel meal-based ration (Oladunjoye et al., 2014). The cyanide level $(0.02 \mathrm{~g} / \mathrm{kg}$ or $20 \mathrm{mg} /$ 
$\mathrm{kg}$ ) of the cassava peels used in this study seems to be relatively low. This may be responsible for the insignificant mortality rate recorded in the experimental rabbits as opposed to the high mortality rate that is usually associated with cyanide poisoning in animals (Ronald, 1991). Mammals' liver detoxifies about $80 \%$ of ingested cyanide to thiocyanate via the mitochondrial rhodanese. However, when absorption rate is significantly greater than the rate of detoxification, the rapid accumulation of free cyanide could occur in the tissues, body fluids, and subsequent onset of poisoning symptoms of the animals (Ronald, 1991). Although it was reported that animal could ingest sublethal doses of cyanide over an extended period without harm in terms of mortality due to rapid detoxification (Mengel, Kramer, Isert, \& Friedberg, 1989), continuous or repeated exposure and subsequent accumulation of cyanide (toxin) in the body fluids, tissues, and organs of the animals for a long period of time (chronic exposure) may predispose the animal to oxidative stress (Lei et al., 2017) and subsequently caused negative effects on biological activities and compromised performance (Halliwell \& Gutteridge, 1989; Oloruntola, Ayodele, Adeyeye, \& Agbede, 2018) as recorded in this study.

Also, the multi-enzyme supplementation's positive significant $(P<0.01 ; 0.05)$ influence on the weight changes of the growing rabbits could be due to improvement of nutrient utilization (Boguhn \& Rodehutscord, 2010; Lukuyu et al., 2014; Yang et al., 2010) and possible breaking down of anti-nutritive fractions (Bimrew, 2014; Lukuyu et al., 2014) in the diets by enzyme complex in the multi-enzyme used in this study. Cellulase breaks down feed fiber to glucose; $\alpha$-amylase converts starch into glucose and maltose; protease shows activity on protein; pectinase breaks down protein into peptides and amino acids; lipase breaks down feed oil and fat to produce energy, while phytase releases bounded phosphorus (Fasiullah, Khandaker, Islam, Kamruzzaman, \& Islam, 2010), and the cumulative effect of these enzymes might be responsible for the improvement in the weight changes observed in this study. The significant $(P<0.05)$ interactive effect of methionine and multi-enzyme supplementation on FWG and DWG of the rabbits in this study revealed the synergy between these two factors and the possibility of one complementing the other to enhance weight gain.

The depressed DM, CP, NDF, and ADF GE digestibility in rabbits fed diet 5 (35\% CPM; 0.56\% MET) compared to those fed other diets in this study might be due to the increase in cyanide concentration in the diet due to CPM inclusion with no enzyme supplementation and insufficient MET in the diet which would have been used by Rhodanase enzyme as the sulfur donor in the detoxification of $\mathrm{HCN}$ in the CPM component of the diet. The use of methionine for detoxification usually makes it unavailable for protein synthesis in the animals and this may induce sulfur AA deficiency in the animals and thermal stress involved in the catabolism of AAs may lead to reduced efficient nutrient utilization with high cyanide (Iyayi \& Odueso, 2003). This further explained the reason behind the depressed growth performance and FCR recorded in rabbits fed diet 5 in this study. Diets furnished with sulfur amino acids for detoxification of the cyanide is necessary for optimal nutrient utilization and performance. This hypothesis may explain the significantly $(P<0.05)$ improvement in DM, OM, CP, ADF, and GE digestibility recorded in this study due to relatively high $(0.83 \% \mathrm{MET})$ methionine supplementation especially in diets containing CPM at 35\%. However, the present findings are consistent with the earlier report of Lukuyu et al. (2014) who observed improved nutrient utilization following increased level of supplementary methionine in broiler chicken's diet. The significant $(P<0.05)$ improvement of nutrient digestibility due to enzyme supplementation in this study agreed with the previous report of Ayodele et al. (2016); in which there was improved crude protein and crude fiber digestibility in growing rabbits by enzyme supplementation. In addition, the potential of endo-enzyme in disruption of fibrous feedstuffs' cell matrix and resultant easy access of endogenous cellulolytic and proteolytic enzymes to digest the entrapped carbohydrate and protein had been reported (Bimrew, 2014). The significant interactive effects $(P<0.01)$ of methionine and enzyme supplementation on $\mathrm{CP}$ and GE digestibility further supported the positive synergic effect of these two factors in ameliorating the negative effect of cyanide associated with $35 \%$ CPM inclusion in diets.

The lower slaughter weight (SLW), carcass weight (CWT), and carcass weight percentage (CWP) recorded for rabbits on diet 5 (35\% CPM; 0.56\% MET) when compared to those fed the rest of the diets in this study further confirms the earlier observations, since cut parts are function of the final live weight. The CWP recorded in this study was higher than that reported by Ayodele et al. (2016) but lower than that reported by Lounaouci-Ouyed, Berchiche, and Gidenne (2003). This variation may be a result of differences in some factors such as breed, age, and treatments among others in the different studies. The observed significant $(P<0.05)$ decrease in CWT and CWP of rabbits due to $C P M$ inclusion $(P<0.05)$ and methionine supplementation $(P<0.01)$ might imply that these factors contributed more to the development of the in-edible portion (such as pelt, distal part of tail, fore and hind legs, and gastrointestinal and urogenital tracts) of the rabbits than the edible portion. The significant $(P<0.05)$ interactive effect of these 2 factors (MET*ENZ) suggests the interdependence of these factors in the laying down of the edible parts of the rabbits under study. In this study, the stability of lung, gallbladder, heart, and spleen across the 
diets may imply the wholesomeness of the diets, because the abnormal increase in the relative internal organ weight of animals may be indicative of their response to toxic compounds in their diets. However, the increase in the liver and kidney weights of rabbits fed diet 5 further confirms the toxicity of $\mathrm{HCN}$ which might be aggravated by low methionine supplementation in the diet. This agreed with an earlier report of Ogunsipe et al. (2015) who fed broiler chicken with cassava plant meal-based diets and found that the liver, kidney, and gizzard weights were higher in birds fed cassava plant meal-based diets than the control diet. The increased liver and kidney physiological activities of the rabbits in this study due to possible residual cyanide might have led to their higher relative weights. The observed decrease in relative weight of liver and kidney due to enzyme supplementation and significant $(P<0.05)$ effect of CPM, methionine, and enzyme may also be indicative of the endogenous enzyme capability and its combination with other factors to remove or ameliorate the negative effect of antinutrients, in particular, $\mathrm{HCN}$ in the rabbit diets.

\section{Conclusion}

The inclusion of cassava peels in the diets at 35\% negatively affected the growth performance of the growing rabbits as a result of the cumulative effect of the cyanide. However, this can be ameliorated by multi-enzyme and high methionine $(0.83 \%)$ supplementation as shown in this study. Further studies are hereby recommended to reveal the economic value and farmers' affordability and acceptability of multi-enzyme and methionine supplementation in producing rabbits on cassava peel-based diets.

\section{Abbreviations \\ ADF: Acid detergent fiber; ANOVA: Analysis of variance; CF: Crude fiber; CP: Crude protein; CPM: Cassava peel meal; CWP: Carcass weight percentage; CWT: Carcass weight; DE: Digestible energy; DFI: Daily feed intake; DM: Dry matter; DWG: Daily weight gain; ENZ: Multi-enzyme; FCR: Feed conversion ratio; Fl: Feed intake; FWG: Final weight gain; IW: Initial weight; MET: Methionine; MOR: Mortality; NDF: Neutral detergent fiber; OM: Organic matter; SLW: Slaughter weight; TFI: Total feed intake}

\section{Acknowledgments}

\section{Not applicable}

\section{Authors' contributions}

ODO and SOA suggested the study. All authors participated in its design and coordination. ODO, SOA, and OAJ carried out the feeding trial, sample collection, and analysis. ODO and SOA carried out statistical data analysis and interpreted the results. ODO, SOA, and JOA searched for pieces of literature. ODO and SOA prepared the first draft of the manuscript. All authors read and approved the final manuscript.

\section{Funding}

This research was funded by the Federal Government of Nigeria Tetfund grant 2014 to which the authors are immensely grateful.

\section{Availability of data and materials}

The datasets generated and analyzed during the current study are available from the corresponding author on reasonable request.

\section{Ethics approval and consent to participate}

The right to conduct the research granted by the Research Committee of the Department of Agricultural Technology, The Federal Polytechnic, Ado Ekiti, Nigeria. The animals were managed following the recommendation and guidelines for applied nutrition experiments in rabbits.

\section{Consent for publication}

Not applicable.

\section{Competing interests}

The authors declare that they have no competing interests.

\section{Author details}

${ }^{1}$ Animal Science Department, Adekunle Ajasin University, Akungba Akoko, Nigeria. ${ }^{2}$ Agricultural Technology Department, The Federal Polytechnic, Ado Ekiti, Nigeria. ${ }^{3}$ Animal Production and Health Department, The Federal University of Technology, Akure, Nigeria.

Received: 27 February 2019 Accepted: 6 June 2019

Published online: 26 June 2019

\section{References}

Adegbola, A. A. (1977). Methionine as an additive to cassava-based diets. In B. Nestel, \& M. Graham (Eds.), Cassava as animal feed: Proceedings of A workshop, University of Guelph, Ottawa, Canada, (pp. 9-17). Ottawa: IDRC.

Adeyeye, S. A., Agbede, J. O., Aletor, V. A., \& Oloruntola, O. D. (2018). Performance and carcass characteristics of growing rabbits fed diets containing graded levels of processed cocoa (Theobroma cocoa) pod husk meal supplemented with multi-enzyme. Journal of Applied Life Sciences International, 17(2), 1-11.

Agunbiade, J. A., Adeyemi, O. A., Fasina, O. E., Ashorobi, B. O., Adebanjo, M. O., \& Waide, O. A. (1999). Cassava peels and leaves in the diet of rabbits: Effect on performance and carcass characteristics. Nigerian Journal of Animal Production, 26, 29-34

Aniebo, A. O. (2012). Appraisal of palm oil and methionine as detoxifying agents of residual cyanide in cassava-based broiler starter diets. International Journal of Food, Agriculture and Veterinary Science, 2(1), 153-161.

AOAC (2000). Official method of analysis. Washington, DC: AOAC International.

Aro, S. O. (2008). Improvement in the nutritive quality of cassava and its byproducts through microbial fermentation. Journal of Biotechnology, 7(25), 4789-4797.

Aro, S. O., Aletor, V. A., Tewe, O. O., \& Agbede, J. O. (2010). Nutritional potentials of cassava tuber wastes: A case study of a cassava starch processing factory in South-western Nigeria. Livestock Research for Rural Development, (11), 22.

Ayodele, S. O., Oloruntola, O. D., \& Agbede, J. O. (2016). Effect of Alchornea cordifolia leaf meal inclusion and enzyme supplementation on performance and digestibility of rabbits. World Rabbit Science, 24, 201-206.

Benitez, L. V. (1989). Amino acid and fatty acid profiles in aquaculture nutrition studies, p. 23- 35. In S. S. De Silva (Ed.), Fish nutrition research in Asia, (vol. 4, p. 166). Manila: In Proc: 3rd Asian Fish Nutrition Network Meeting. Asian fish. Society Special Publication. Asian Fisheries Society.

Bimrew, A. (2014). Effect of common feed enzymes on nutrient utilization of monogastric animals. International Journal of Biotechnology and Molecular Biology Research, 5(4), 27-34.

Boguhn, J., \& Rodehutscord, M. (2010). Effect of nonstarch polysaccharidehydrolyzing on performance and amino acid digestibility in Turkey. Poultry Science, 89, 505-513.

Burns, A. A., Gleadow, R. M., Zacarias, A. M., Cuambe, C. E., Miller, R. E., \& Cavagnaro, T. R. (2012). Variations in the chemical composition of cassava (Manihot esculenta Crantz) leaves and roots as affected by genotypic and environmental variation. Journal of Agricultural and Food Chemistry, 60(19), 4946-4956. https://doi.org/10.1021/jf2047288.

EGRAN (2001). Technical note: Attempts to harmonize chemical analyses of feeds and feces, for rabbit feed evaluation. World Rabbit Science, 9(2), 57-64.

Enneking, D., \& Wink, M. (2000). Towards the elimination of antinutritional factors in grain legumes. In R. Knight (Ed.), Linking research and marketing opportunities for pulses in the 21st century: Proceedings of the third international food legumes research conference, held in Adelaide, South Australia, 22-26 September 1997, (pp. 671-683). Dordrecht: Kluwer Academic Publishers.

Fasiullah, M. S., Khandaker, Z. H., Islam, K. M. S., Kamruzzaman, M., \& Islam, R. (2010). Effect of dietary enzyme supplementation on nutrient utilization and 
growth performance of rabbit. International Journal of Biological Research, 1(3), 17-21.

Fernández-Carmona, J., Blas, E., Pascual, J. J., Maertens, L., Gidenne, T., Xiccato, G., \& García, J. (2003). Recommendations and guidelines for applied nutrition experiments in rabbits. World Rabbit Science, 13, 209-228. https://doi.org/10. 4995/wrs.2005.516.

Francis, G., Makkar, H. P. S., \& Becker, K. (2001). The antinutritional factors present in plant-derived alternate fish feed ingredients and their effects in fish. Aquaculture., 119, 197-227.

García-Ruiz, A. l., García Palomares, J., García-Rebollar, P., Chamorro, S., Carabaño, R., \& de Blas, C. (2006). Effect of protein source and enzyme supplementation on ileal protein digestibility and fattening performance in rabbits. Spanish Journal of Agricultural Research, 4, 297-303. https://doi.org/10.5424/sjar/ 2006044-207.

Goering, H. K., \& Van Soest, P. J. (1970). Forage Fiber Analysis: Apparatus, Reagents, Procedures and some Applications. Washington, DC: USDA-ARS Agricultural Handbook 379.

Halliwell, B. E., \& Gutteridge, J. M. C. (1989). Lipid peroxidation: A radical chain reaction, free radical in biology and medicine, (2nd ed., pp. 188-218). New York: Oxford University Press.

INRA., CIRAD., AFZ., FAO (2012). Cassava peels, fresh. Feedipedia-animal feed resources information system http://www.feedipedia.org/node/11946.

Iyayi, E. A., \& Odueso, O. M. (2003). Response of some metabolic and biochemical indices in rabbits fed varying levels of dietary cyanide. African Journal of Biomedical Research, 6(1), 43-47.

Kataria, R. (2014). Proximate nutritional evaluation of maize and rice gluten-free cereal. Journal of Nursing and Health Sciences, 3(2), 1-6.

Kiarie, E., Romero, L. F., \& Nyachoti, C. M. (2013). The role of added feed enzymes on promoting gut health in swine and poultry. Nutrition Research Review, 26, 71-88. https://doi.org/10.1017/50954422413000048.

Lei, Y., Guanghui, Z., Xi, W., Yingting, W., Xialu, L., Fangfang, Y., ... Lammi, M. J. (2017). Cellular responses to T-2 toxin and/ or deoxynivalenol that induce cartilage damage are not specific to chondrocytes. Scientific Reports, 7, 2231. https://doi.org/10.1038/s41598-017-02568-5.

Lounaouci-Ouyed, G., Berchiche, M., \& Gidenne, T. (2003). Effect of substitution of soybean meal-alfafa-maize by a combination of field bean or pea with hard wheat bran on digestion and growth performance in rabbits in Algeria. World Rabbit Science, 22, 137-146.

Lukuyu, B., Okike, I., Duncan, A., Beveridge, M., \& Blümmel, M. (2014). Use of cassava in livestock and aquaculture feeding programs. ILRI Discussion Paper 25. Nairobi: International Livestock Research Institute, Pp. vi 4-7, 23.

Mengel, K., Kramer, W., Isert, B., \& Friedberg, K. D. (1989). Thiosulphate and hydroxocobalamin prophylaxis in progressive cyanide poisoning in Guineapigs. Toxicology, 54, 335-342.

Midau, A., Augustine, C., Yakubu, B., Yahaya, S. M., Kibon, A., \& Udoyong, A. O. (2011). Performance of broiler chicken fed enzyme supplemented cassava peel meal based diets. International Journal of Sustainable Agriculture, 3(1), 1-4.

Oboh, G., Akindahunsi, A. A., \& Oshodi, A. A. (2002). Nutrient and anti-nutrient content of Aspergillus niger fermented cassava products (flour and gari). Journal of Food Composition and Analysis, 15, 617-622.

Ogunsipe, M. H., Adejumo, J. O., Agbede, J. O., \& Asaniyan, E. K. (2015). Effect of roxazyme G2G supplementation on cassava plant meal fed to broiler chickens. Livestock Research for Rural Development, (12), 27.

Oke, O. L. (1978). Problems in the use of cassava as animal feed. Animal Feed Science and Technology, 3, 345-380.

Oladunjoye, I. O., Ojebiyi, O. O., \& Rafiu, T. A. (2014). High methionine supplementation improves the nutritional value of cassava peel meal for broiler chicken. Livestock Research for Rural Development, 26(4).

Oloruntanyan, B., Ayoola, M. A., Fayeye, T. R., Olagunju, T. A., \& Olorunsanya, E. O. (2007). Effect of replacing maize with sun-dried cassava waste meal on growth performance and carcass characteristics of meat type rabbits. Livestock Research for Rural Development, 19(4).

Oloruntola, O. D. (2018). Influence of enzyme supplementation on rabbits fed rumen liquor with poultry waste fermented cassava peels based diets. Animal Research International, 15(1), 2950-2964.

Oloruntola, O. D., Agbede, J. O., Onibi, G. E., \& Igbasan, F. A. (2015). Composition of cassava (Manihot spp.) peels fermented with bovine rumen liquor and different nitrogen sources. Journal of Global Agriculture and Ecology, 2(1), 26-35.
Oloruntola, O. D., Agbede, J. O., Onibi, G. E., \& Igbasan, F. A. (2016). Replacement value of rumen liquor fermented cassava peels for maize in growing rabbit diets. Archivos de Zootecnia, 65(249), 89-97.

Oloruntola, O. D., Ayodele, S. O., Adeyeye, S. O., \& Agbede, J. O. (2018). Performance, haemato-biochemical indices and antioxidant status of growing rabbits fed on diets supplemented with Mucuna pruriens leaf meal. World Rabbit Science, 26, 277-285. https://doi.org/10.4995/wrs.2018.10182.

Olowoyeye, J. C. (2016). Nutritive potential of cassava root waste meals and cassava leaf meal-mixed diets for broiler chickensPh.D. Thesis Submitted to the School of Postgraduate Studies. Akure: The Federal University of Technology.

Oluremi, O. I. A., \& Nwosu, A. (2002). The replacement of soaked cassava peels on weaning rabbits. The Journal of Food Technology in Africa, 7(1), 12-15.

Omole, T. A. (1990). The use of cassava in rabbit feeding: A review. Journal of Applied Rabbit Research, 13(3-4), 184-188.

Omole, T. A., \& Sonaiya, E. B. (1981). The effect of protein sources and methionine supplementation of cassava peel meal utilization by growing rabbits. Nutrition Reports International, 23(4), 729-737.

Ronald, E. (1991). Cyanide hazards to fish, wildlife, and invertebrates: A synoptic review- U.S. Fish and Wildlife Service. Biological Report, 85(1.23), 1-1.58.

Ty, C., Preston, T. R., \& Ly, J. (2003). The use of ensiled cassava leaves in diets for growing pigs. 2 . The influence of type of palm oil and cassava leaf maturity on digestibility and $\mathrm{N}$ balance for growing pigs. Livestock Research for Rural Development, (8), 15.

Yang, Z. B., Yang, W. R., Jiang, S. Z., Zhang, G. G., Zhang, Q. Q., \& Slow, K. C (2010). Effects of a thermotolerant multi-enzyme product on nutrient and energy utilization of broilers fed mash or crumbled corn-soybean meal diets. Journal of Applied Poultry Research, 19, 38-45.

\section{Publisher's Note}

Springer Nature remains neutral with regard to jurisdictional claims in published maps and institutional affiliations.

\section{Submit your manuscript to a SpringerOpen ${ }^{\circ}$ journal and benefit from:}

- Convenient online submission

- Rigorous peer review

- Open access: articles freely available online

- High visibility within the field

- Retaining the copyright to your article

Submit your next manuscript at $\boldsymbol{\nabla}$ springeropen.com 